\title{
Chapter 3 \\ Hope as a Virtue in the Middle Ages
}

\author{
Andrew Pinsent
}

\begin{abstract}
As a theological disposition revealed in Scripture, the recognition of hope as an important virtue coincided with the radical transformation in virtue ethics in the early Middle Ages. As the ideals of pagan antiquity gave way to the Christian aspirations for the Kingdom of Heaven, early work on hope was strongly influenced by writers with a monastic background, such as Pope St Gregory the Great. The rise of scholasticism in the twelfth and thirteenth centuries, however, gave an impetus to finding a coherent account of virtue ethics that would incorporate hope along with the other theological virtues and revealed attributes of perfection, such as the gifts and fruits of the Holy Spirit. This chapter examines, in particular, the attempt of St Thomas Aquinas to develop such an account and the role of hope in this account, drawing from new research in experimental psychology. The chapter concludes by considering briefly the transposition of the medieval account of hope to aspects of contemporary life.
\end{abstract}

\subsection{Introduction}

The crescendo of crises at the end of Roman Empire helped to consolidate a radical change in the principles of virtue ethics for the subsequent millennium. With the decay of the Empire, there was a massive stripping away of what ordinarily constituted the means of support and material basis for life. In its place, there was a growing focus on what Christian converts regarded as the more enduring basis of existence that had taken root in them through faith, a life of divine grace that was also given new and concrete expressions, especially with the rise of monasticism. This new life began indeed in this world but was oriented towards the Kingdom of Heaven, the eternal country of the saints.

\footnotetext{
A. Pinsent $(\square)$

Faculty of Theology and Religion, Ian Ramsey Centre for Science and Religion, University of Oxford, Oxford, UK

e-mail: andrew.pinsent@hmc.ox.ac.uk
}

S. C. van den Heuvel (ed.), Historical and Multidisciplinary Perspectives on Hope, https://doi.org/10.1007/978-3-030-46489-9_3 
Virtue ethics in the Middle Ages, spanning roughly the abdication of the last Western Roman Emperor (476) to the Fall of Constantinople (1453), reflects these changes and therefore departs in many significant ways from the accounts of classical Greco-Roman antiquity. Many signs of this transformation can be found in the works of Pope St Gregory the Great (d. 604), often regarded as a pivot figure between the Greco-Roman and medieval worlds (Leyser 2000, pp. 132-133). In his massive and influential allegorical commentary on the Book of Job, Gregory makes frequent reference to attributes of the moral life that are drawn uniquely from revelation, such as the seven gifts of the Holy Spirit. ${ }^{1}$ Among the most important of these attributes is the Scriptural triad of faith (fides), hope (spes), and love (caritas) ${ }^{2}$ which Gregory describes, for example, as being invited by the virtues into everything they do (I, 46), and being represented allegorically in Scripture by the three daughters of Job, the most beautiful women in the land (Job 42:13-15), who are born to Job after his crisis (XXXV.13). Although Gregory does not use the phrase himself, these virtues became known to the Middle Ages as the theological virtues.

Gregory therefore set a challenge that would persist throughout the Middle Ages of producing a virtue ethics suitable for the new Christian person and societies, oriented in a concrete way towards the Kingdom of Heaven. A priority of this project was to include those dispositions revealed only in Scripture that played such a prominent role in Gregory's work, namely the theological virtues and gifts of the Holy Spirit. During the twelfth century, however, and consistent with a renewed interest in Aristotelian philosophy, there was a growing formal recognition of the existence of naturally acquired virtues next to the salvific virtues and gifts of divine grace. ${ }^{3}$ During this century, one can therefore discern two main streams of moral thought: the monastic morality represented, for example, by Anselm of Canterbury, Bernard of Clairvaux, Hugh of Folieto, and Hugh of Saint Victor; and the protoscholastic approach of John of Salisbury, Peter Abelard, and Stephen Langton. By the end of the fifteenth century, the scholastics dominated the teaching of ethics in European universities, drawing the materials for their commentaries largely from the Nicomachean Ethics. As one consequence, although dispositions of revelation, such as theological hope and the gifts of the Holy Spirit, were still formally acknowledged as being of paramount importance in the concluding years of the Middle Ages, in practice the ground was being prepared for their gradual eclipse and relegation to mystical theology. ${ }^{4}$

\footnotetext{
${ }^{1}$ Moralia in Iob; the anonymous translation in 1844 has been reprinted (Gregory 2012).

${ }^{2}$ The perfective attributes of faith ( fides), hope (spes), and love (caritas), are highlighted twice by St Paul in 1 Thessalonians 1:3 and 5:8, as well as 1 Corinthians 13; this triad had already been discussed by St Augustine of Hippo and St Gregory of Nyssa among others.

${ }^{3}$ See Bejczy (2005). For an outstanding introduction to the scholastic project, see Southern (1997).

${ }^{4}$ For the trends in virtue ethics at the end of the Middle Ages and into the early modern period, see, for example, Pinckaers (1995, pp. 240-257).
} 
Given these sweeping changes over many centuries, how, then, is it possible to characterize the topic of hope in the Middle Ages? Rather than an eclectic survey, I have chosen in this chapter to examine a single account in detail: the account of hope by St Thomas Aquinas in the Summa theologiae. Among the reasons for making this selection is the fact that Aquinas has an enduring influence and reputation, and that he continues to be studied extensively today. In addition, Aquinas in his account of hope draws together a vast range of materials from throughout the prior Middle Ages on this topic, including from Ambrose, Augustine, Gregory, John of Damascus, and Peter Lombard, among others. On this account, Aquinas can be interpreted as offering a cumulative summary of prior medieval work, while also applying the methods of the neo-scholastics that had become available by the thirteenth century.

What is also significant is that Aquinas draws extensively from both the neo-scholastics and the monastic moralists to present an integrated account of human flourishing, an account that appears to emulate and even vastly exceed the systematic detail and comprehensiveness of Aristotle's virtue ethics. Crucially, however, this account also incorporates the key attributes of Christian perfection that were hallowed throughout the Middle Ages, such as the gifts of the Holy Spirit and the theological virtues. Although some respected contemporary commentators have tended to cast doubt on the success of this achievement, ${ }^{5}$ the prospect of a single and cohesive account of human flourishing in the life of grace, an account with an integral place for the theological virtue of hope, deserves careful examination.

Where then is Aquinas's account to be found? Although references to virtues, including the virtue of hope, can be found across many of his works, the most detailed systematic account is the vast second part of his influential Summa theologiae (ST) and especially ST II-II, qq.1-170. This account is structured around seven principal virtues, starting with the theological virtues of faith, hope, and love, followed by Christianized versions of the four cardinal virtues of prudence, justice, courage, and temperance.

\subsection{Hope in the Summa Theologiae}

On Aquinas's account, the theological virtue of hope is relatively straightforward to describe in outline, namely it is the good desire for the difficult but possible goal of attaining eternal happiness with God in the Kingdom of Heaven (ST II-II, q.17, a.2). In other words, hope is the subjective desire for the proper completion or fruitfulness of a human life. Nevertheless, the meaning of such perfection differs in some

\footnotetext{
${ }^{5}$ See, for example, MacIntyre (2007, p. 178). MacIntyre here describes Aquinas's treatment of the virtues as 'questionable' at key points and goes on to suggest that we ought to be suspicious of the apparently exhaustive and consistent classificatory scheme by which Aquinas presents his table of virtues. Whatever else may be said, MacIntyre, at least, does not see how Aquinas's virtue ethics makes sense.
} 
important ways from the ideals of classical pagan antiquity as found, for example, in Aristotle's Nicomachean Ethics. For Aquinas, the life that human beings possess by virtue of being born physically needs to be transformed by God's gift into a new kind of life, the life of grace that is revealed and made possible through divine revelation. ${ }^{6}$ This new life, which ordinarily begins with the second birth of Baptism and culminates ultimately with the vision of God in the resurrected human body, is described in Scripture as a sharing in or partaking of the divine nature (2 Peter 1:4). On this account, if the person of Jesus Christ, true God and true man, is like a bridge connecting heaven and earth, the life of grace enables people to cross that bridge and live in the presence of God. ${ }^{7}$ This new life enables a relationship with God that is described in intimate and interpersonal terms, such as "Father," "friend," or "spouse," the latter instance corresponding to heaven being described as the "wedding feast of the Lamb." 8

Consistent with the notion of a different kind of life to that of the classical ideals of the Greco-Roman world, Aquinas also offers a markedly different account of the virtues of this new life compared to those found in the Nicomachean Ethics. As the first principles of this new life, as described in ST II-II.1-46, he introduces the triad of faith (fides), hope (spes), and divine love (caritas), which are mentioned repeatedly in Scripture and traditional commentaries as being associated with a life that is ordered to salvation. ${ }^{9}$ Following customary practice, he describes these dispositions as the theological virtues, so named first, he says, because they direct us rightly to God; second, because they are infused by God alone; and third, because these virtues are not made known except by revelation (ST I-II, q.62, a.1).

Aquinas's treatment of hope, covered in ST II-II, qq.17-22, is the shortest, at 34 articles, of all the seven principal virtues of ST II-II, qq. $1-170 .{ }^{10}$ This description also has the simplest structure: there is, in fact, only one question on hope, considered in itself (q.17), in which Aquinas argues, first, that hope is properly a virtue (a.1) and then that its object is eternal happiness (a.2),

Wherefore the good which we ought to hope for from God properly and chiefly is the infinite good, which is proportionate to the power of our divine helper, since it belongs to an infinite power to lead anyone to an infinite good. Such a good is eternal life, which consists in the enjoyment of God Himself. For we should hope from Him for nothing less than Himself,

\footnotetext{
${ }^{6}$ For a recent account of this life, see Stump (2018, pp. 197-230).

${ }^{7}$ The image of the bridge is taken from another Dominican of the Middle Ages, St Catherine of Siena (d. 1380). See Thorold and Marcellino (2011, p. 45).

${ }^{8}$ The term "Father" is found in the opening of the most famous Christian prayer, the Lord's Prayer or Our Father (Matthew 6:9-13; Luke 11:2-3); the term "friend" is found in John 15:15; and the wedding feast of the Lamb is mentioned in Revelation 19:9.

${ }^{9}$ Faith in relation to salvation, for example, is cited in Romans 3:28 and Galatians 2:16; hope is mentioned in Romans 8:24; and love in 1 Corinthians 2:9 and 1 John 3:17.

${ }^{10}$ For comparison, here are the figures for all the seven principal virtues of ST II-II, qq.1-170: there are 81 articles for faith; 34 for hope; 142 for love; 59 for prudence; 304 for justice; 66 for courage; and 129 for temperance.
} 
since His goodness, whereby He imparts good things to His creature, is no less than His Essence. Therefore the proper and principal object of hope is eternal happiness. ${ }^{11}$

In other words, the hope that is the object of the theological virtue of hope is the good of eternal life itself, consisting principally of the enjoyment of God. Specifically, Aquinas defines hope as denoting a movement or a stretching forth of the appetite towards this supreme but arduous good. ${ }^{12}$ In the same and other articles of this question, Aquinas will clarify that this hope properly belongs only to the one who has it (q.17, a.3), that the only and proper grounding of hope is God (a.4), that hope is numbered among the theological virtues (a.5), but is distinct from the others (a.6), that faith precedes hope (a.7), and that hope precedes love, the greatest of the theological virtues, in the order of generation (a.8).

This question is followed by a single question on the subject of hope (q.18), in which Aquinas underlines that hope belongs to the will or rational appetite (a.1), and is solely a virtue of the wayfarer state, in other words a virtue of the life of grace in the present life or in purgatory $(\mathrm{a} .3$, co.). Hope cannot be in the saints enjoying eternal life, for they already possess that for which they hoped in this life (a.2); and hope cannot be in the damned, because they cannot escape damnation and know that they cannot escape (a.3). Aquinas also argues that there is certainty in hope, by which he means that there is no deficiency in God's power and mercy to bring a person to salvation, even though some people do, in fact, fail to gain this happiness through their own choice of deadly sin (a.4, especially ad 3).

The next question (q.19) deals with an aspect of Aquinas's treatment of the virtues that is still often overlooked by commentators, namely that he connects the principal virtues with three further kinds of perfective attributes: first, the dispositions (habitus) that are the 7 gifts of the Holy Spirit; second, the beatitudes, which are promissory micro-narratives; and, finally, the 12 fruits of the Holy Spirit. In other words, Aquinas's virtue ethics is really a virtue-and-gift ethics with two kinds of actualizations, namely beatitudes and fruits. For the virtue of hope, the associated gift of the Spirit is filial fear (a.1-11), which fear, as Aquinas explains in q.19, a.2, is not the servile fear of punishment but more akin to disappointing a beloved parent. As regards the beatitudes, Aquinas in q.19, a.12 ad 3 associates the virtue of hope with the last beatitude that deals with spiritual perfection (Matthew 5:9, "Blessed are the peacemakers; they shall be called children of God") and the gift of fear with the first beatitude (Matthew 5:3, "Blessed are the poor in spirit; for theirs is the kingdom

\footnotetext{
${ }^{11}$ ST II-II, q.17, a.2, "Et ideo bonum quod proprie et principaliter a Deo sperare debemus est bonum infinitum, quod proportionatur virtuti Dei adiuvantis, nam infinitae virtutis est proprium ad infinitum bonum perducere. Hoc autem bonum est vita aeterna, quae in fruitione ipsius Dei consistit, non enim minus aliquid ab eo sperandum est quam sit ipse, cum non sit minor eius bonitas, per quam bona creaturae communicat, quam eius essentia. Et ideo proprium et principale obiectum spei est beatitudo aeterna." In this chapter, I use the translation of the Fathers of the English Dominican Province (Aquinas 1911) because it has become standard and because there are not many places where I could improve on it significantly.

${ }^{12}$ ST II-II, q.17, a.3, “... spes autem importat quendam motum sive protensionem appetitus in aliquod bonum arduum."
} 
of heaven"). These associations, together with the promissory form of the beatitudes in general, suggests that the kind of perfective actualization that is called a beatitude belongs especially closely to the virtue of hope. ${ }^{13}$ In q.19, a.12, Aquinas also assigns modesty, continency, and chastity to hope as the corresponding fruits of the Spirit.

As the concluding parts of his account of hope, Aquinas presents the dispositions that are opposed to hope, namely despair (q.20) and presumption (q.21), followed by a final question (q.22) on the precepts of hope and fear. As regards hope, Aquinas argues that all the promises contained in the Law are incitements to hope (q.22, a.1); as regards fear, he claims that this is a kind of principle of all observances connected with reverence for God.

\subsection{The Second-Person Perspective on Hope}

In order to interpret how the various attributes associated with hope in ST II-II qq.17-19 fit together, it is important to offer at least a brief account of how Aquinas's virtue ethics works in general, especially as Aquinas describes these virtues as infused rather than acquired by habituation, and also as integrating in some way with corresponding gifts of the Spirit, as well as beatitudes and fruits. In this section, I offer a summary of my own solution based on the second-person perspective, not only because it has many explanatory benefits but also because I am not aware of any alternative at the present time that offers any prospect of seeing Aquinas's virtueand-gift ethics as an integrated whole.

What does this virtue-gift-beatitude-fruit (VGBF) structure imply for understanding hope? As I have argued in detail elsewhere, Aquinas's account of virtue ethics in the $S T$ is definitely non-Aristotelian and he prioritizes what he calls infused virtues or, more precisely, virtues and gifts that are infused directly by God rather than acquired by human effort (Pinsent 2012, pp. 12-23). As I have also argued elsewhere, for these infused virtues to be philosophically interesting rather than skyhooks from revelation, there is a need to ground the notion of infusion on a metaphor that connects these claims to embodied experience (Pinsent 2017, pp. 75-77).

The metaphor I have proposed is what psychologists today call shared or joint attention, which is also closely associated with second-person relatedness (Pinsent 2012, pp. 41-63). On this account, dispositions are infused in the context of a triadic arrangement that involves two personal agents that share awareness of shared focus on some object, like a parent pointing out something to a child or playing a game with a child. In this context of this interaction, the stance towards the object is shared between the first and second person, providing a practical metaphor for the way in

\footnotetext{
${ }^{13}$ The genre of the beatitudes of Matthew 5:3-12 varies depending on one's perspective. For those setting out on the Christian life, the beatitudes are the promises of Jesus Christ, encouraging perseverance, and are therefore very closely associated with the virtue of hope in the present world. For those who finish the race well and attain heaven, the beatitudes become the story of their lives.
} 
which a disposition may be infused from person to person. ${ }^{14}$ Such dispositional infusion is commonplace in everyday interactions, such as when a first person likes a second person and begins, often subconsciously, to imitate that person. For Aquinas's account of flourishing in grace, the second person is the Holy Spirit, and the vast suite of virtues and gifts described in his account are infused and actualized in the context of joint attention or second-person relatedness with God. On this account, one is moved by God spiritually, in ways that are reinforced by hallowed stories and liturgical practices, becoming God-like by loving with God what God loves.

On this account, hope involves God not only as the difficult-to-obtain future object of one's attentive desire but also as one's present co-attending subject, a claim that is consistent with the details of Aquinas's claims about the virtue of hope in $S T$ II-II, q.17, a.1 as follows:

... the act of hope, whereof we speak now, attains God. For, as we have already stated (ST III, q.40, a.1), when we were treating of the passion of hope, the object of hope is a future good, difficult but possible to obtain. Now a thing is possible to us in two ways: first, by ourselves; secondly, by means of others, as stated in Ethic. iii. Wherefore, in so far as we hope for anything as being possible to us by means of the Divine assistance, our hope attains God Himself, on Whose help it leans. ${ }^{15}$

The notion of "leaning on," or being supported by, God's help is repeated in the following article:

As stated above (a.1), the hope of which we speak now, attains God by leaning on His help in order to obtain the hoped for good. ${ }^{16}$

These texts confirm that hope is indeed about attaining God, but not simply as a remote object of desire. Instead, the very act of hoping also involves the side-by-side metaphor of "leaning on" God, consistent with the description of the Holy Spirit as the paraclete (John 14:16, 26) meaning the one called to one's side, as well as the second-person interpretation of Aquinas's virtue-and-gift ethics in general, in which the Holy Spirit is the co-attending subject who moves oneself in the manner of a second person.

This point can be expanded fruitfully if one considers the general question of how it is possible to know any person well, an especially important question given that Scripture sometimes describes salvation or the condition of salvation in terms of

\footnotetext{
${ }^{14} \mathrm{By}$ 'stance', I mean here a conative attitude consequent upon understanding. This description of a stance is adapted slightly from Eleonore Stump (2011, p. 41). The description of joint attention in terms of a shared awareness of shared focus, along with a shared stance, is drawn from Hobson (2005, p. 185).

${ }^{15}$ ST II-II, q.17, a.1 co., "Actus autem spei de qua nunc loquimur attingit ad Deum. Ut enim supra dictum est, cum de passione spei ageretur, obiectum spei est bonum futurum arduum possibile haberi. Possibile autem est aliquid nobis dupliciter, uno modo, per nos ipsos; alio modo, per alios; ut patet in III Ethic. Inquantum igitur speramus aliquid ut possibile nobis per divinum auxilium, spes nostra attingit ad ipsum Deum, cuius auxilio innititur."

${ }^{16} S T$ II-II, a.17, a.2 co., “. . s sicut dictum est, spes de qua loquimur attingit Deum innitens eius auxilio ad consequendum bonum speratum."
} 
"knowing God." ${ }^{\prime 17}$ Experience teaches that persons do not grow in friendship simply by looking at one another but rather by interacting with one another through diverse good and challenging contexts. As a consequence, if the issue at stake is that of knowing God, then it is plausible that interacting with God in the manner of joint attention is precisely what is needed to prepare to see God face-to-face in a state of divine friendship. Moreover, this interpretation answers one of the objections to hope, namely how it is possible to desire heavenly happiness without an experience of what this happiness is like, given that "Eye has not seen, nor ear heard, nor has the human heart conceived what God has prepared for those who love him" (1 Corinthians 2:9). The answer is that the act of hope does give a foretaste of this happiness insofar as it attains to God, albeit indirectly, even though the one who hopes does not yet see the face of God in glory.

The second-person perspective also sheds light on the relationship of hope with love, an issue that Aquinas addresses in ST II-II, q.17, a.8 as follows,

Now there is a perfect, and an imperfect love. Perfect love is that whereby a man is loved in himself, as when someone wishes a person some good for his own sake; thus a man loves his friend. Imperfect love is that whereby a man love something, not for its own sake, but that he may obtain that good for himself; thus a man loves what he desires. The first love of God pertains to charity, which adheres to God for His own sake; while hope pertains to the second love, since he that hopes, intends to obtain possession of something for himself. ${ }^{18}$

One may interpret this passage by means of the joint attention metaphor as follows. Although both hope and love are directed to the ultimate good of eternal life with God, the motivation of hope is that one obtains that good for one's own sake, whereas the motivation of love is a desire that one obtains that good for God's sake. ${ }^{19}$ With this act of love, one rejoices in the joy of the second person, an ecstasy in the sense of the Greek word ekstasis, meaning to stand outside oneself. ${ }^{20}$ In other words, although both hope and love involve harmonizing one's desire with what

\footnotetext{
${ }^{17}$ See Matthew 7:23 and Luke 13:27.

${ }^{18}$ ST II-II, q. 17, a.8 co., "Amor autem quidam est perfectus, quidam imperfectus. Perfectus quidem amor est quo aliquis secundum se amatur, ut puta cui aliquis vult bonum, sicut homo amat amicum. Imperfectus amor est quo quis amat aliquid non secundum ipsum, sed ut illud bonum sibi ipsi proveniat, sicut homo amat rem quam concupiscit. Primus autem amor Dei pertinet ad caritatem, quae inhaeret Deo secundum seipsum, sed spes pertinet ad secundum amorem, quia ille qui sperat aliquid sibi obtinere intendit."

${ }^{19}$ With this love, one's desire for God can itself be described as God-like, insofar as Scripture and Tradition describe the Holy Spirit as Love. This union as the goal of the virtue of love is noted in ST II-II, q.17, a.3, “... we must observe that love and hope differ in this, that love denotes union between lover and beloved, while hope denotes a movement or a stretching forth of the appetite towards an arduous good...."

${ }^{20}$ Some people may recognize this experience, or at least its human analogues. Nevertheless, most people would also agree that even its human analogues are rare, especially as such love typically involves sacrifices in which one chooses for the sake of love what one would not choose for oneself in the absence of love. Indeed, much of what goes by the name of "love," even in a benevolent sense, begins with and may not progress beyond a refined version of first-person desire, or mutual first-person desires.
} 
God wills for one's life, the ultimate motivation of hope is first-personal, whereas the ecstatic motivation of love is second-personal. This interpretation supports the notion that hope is an especially "natural" theological virtue for human beings, not simply because it happens to pertain to this life with which we are familiar, but because human desire tends, ordinarily or at least initially, to be first-personal. ${ }^{21}$

This second-person approach also sheds some light on the fruits of the Spirit associated with hope noted above, namely modesty, continency, and chastity. As I have also argued elsewhere, these fruits can helpfully be interpreted in a secondpersonal way as resonances, a term drawn from a vast range of phenomena in physics in which two systems are in near-perfect harmony and then reinforce one another in disproportionately exaggerated way. Two persons can also resonate when they align almost perfectly, like singers or dancers attaining a near-perfect harmony, and this account seems to work well, both subjectively and objectively, as a metaphor for the fruits of the Spirit in Aquinas's VGBF account (Pinsent 2012, pp. 84-99).

As noted previously, the particular fruits that Aquinas assigns to hope are modesty, continence, and chastity (q.19, a.12), but this assignment is puzzling at first insofar as the connotations of these attributes are not obviously or intuitively associated with hope. In traditional virtue ethics, one would expect the attributes signified by the names of these fruits to be connected more intuitively with the virtue of temperance, which is an association that Aquinas also makes, albeit indirectly. ${ }^{22}$

A second-person interpretation of hope, however, may help to explain its more direct connection with modesty, continence, and chastity. While it is true that hope looks towards future happiness in which the saints see God face-to-face, a secondperson interpretation also involves God already being present, spiritually, as the co-attending subject of one's attention. Hope is not, therefore, solely about future happiness, but also involves the present enjoyment of at least a foreshadowing of this happiness. And the spiritual fullness consequent upon enjoying the company of one's true beloved excludes the temptations of competing and false loves that undermine modesty, continence, and chastity. On this account, these fruits do not signify any kind of emptiness or lack of love, but rather being made whole and strong to resist temptations by virtue of being full of the genuine love of one's true beloved. $^{23}$

The second-person framework also helps to put into context the next two questions (qq.20-21), on despair and presumption respectively, as well as the final question (q.22) on the precepts of hope and fear. A striking aspect of these three questions is how closely Aquinas associates the virtue and the appended gift of fear, consistent with Aquinas offering a virtue-and-gift ethics. He also classifies despair

\footnotetext{
${ }^{21}$ The narratives of saints throughout history suggest that it is a tremendous achievement of grace, typically involving time and the kind of suffering described in the first clauses of the early beatitudes, for the motivation of one's desire to become truly second-personal.

${ }^{22}$ See $S T$ II-II, q.141, a.1 ad 3.

${ }^{23}$ I am grateful to Eleonore Stump for making this suggestion.
} 
and presumption as sins, and despair as the worst of sins (q.20, a.3). This classification also makes sense in second-person terms, since despair represents an absolute refusal to align with God's stance in regard to one's own life, given that salvation is always possible, and greatly desired by God for any created personal being who is not already in hell. Despair is therefore self-fulfilling, since the lack of alignment makes interpersonal union impossible with God, which in turns cuts off the hope of heaven.

Presumption (q.21) also breaks the relationship with God, insofar as one relies on oneself rather than God or one trusts inordinately in divine mercy or power without repentance. Just as, in the case of despair, one refuses to share God's stance about the possibility of salvation, in the case of presumption, one refuses to share God's stance about the means of salvation, namely union with the Holy Spirit in the life of grace. Hence by its very act, presumption precludes divine joint attention and friendship.

As regards the precepts of hope and fear, Aquinas also describes them in ways that are also very consistent with the second-person perspective. He argues that all the promises contained in the Law are incitements to hope (q.22, a.1), and promising, in which "I" promise "you," is plausibly an inherently second-personal act. ${ }^{24}$ As regards fear, Aquinas argues that filial fear, which is the gift of the Spirit, "is a sort of genus in respect of the love of God, and a kind of principle of all observances connected with reverence for God." 25 So this filial fear is closely related to love, as in the case of the child fearing to disappoint a beloved parent, and is therefore, by implication, also second-personal.

\subsection{The Object of Hope}

The second-person interpretation of hope emphasizes the central theme of hope as the present and anticipated union of the created and graced human person with the uncreated personal God of love. Even without this interpretation, however, union with God and the enjoyment of God is plainly the key object of hope as shown, for example, in the words of $S T$ II-II, q.1, a.2 considered previously.

From one's present perspective, however, a desire for God may seem rather esoteric and difficult to fill out with any kind of imaginative content. Indeed, as noted previously in reference to 1 Cor 2:9, one of the striking differences between the Christian and Aristotelian approaches to human flourishing is that, in the Christian case, the goal of one's desires cannot be properly known or perceived in advance of its attainment. This claim does not mean, however, that nothing can be known about what is associated with this goal. Indeed, Aquinas has some very

\footnotetext{
${ }^{24}$ This theme is explored in Darwall (2013, pp. 131-154).

${ }^{25}$ ST II-II, q.22, a.2, "Sed timor filialis, qui reverentiam exhibet Deo, est quasi quoddam genus ad dilectionem Dei, et principium quoddam omnium eorum quae in Dei reverentiam observantur."
} 
concrete descriptions of these concomitant goods as can be seen, for example, in his prayer for the attainment of heaven:

God of all consolation, you who see nothing in us but what you have given us, I invoke your help: that after this life has run its course, grant me knowledge of you, the first truth, and enjoyment of your divine majesty.

O most bountiful rewarder, endow my body with beauty of splendour, with swift responsiveness to all commands, with complete subservience to the spirit, and with freedom from all vulnerability. Add to these an abundance of your riches, a river of delights, and a flood of other goods. So that I may enjoy your solace above me, a delightful garden beneath my feet, the glorification of body and soul within me, and the sweet companionship of men and angels about me.

With you, most merciful Father, may my mind attain the enlightenment of wisdom, my desire what is truly desirable, and my courage the praise of triumph. There, with you, is refuge from all dangers, multitude of dwelling places, and harmony of wills. There, with you, resides the cheerfulness of spring, the brilliance of summer, the fruitfulness of autumn, and the gentle repose of winter.

Give me, O Lord my God, that life without death and that joy without sorrow where there is the greatest freedom, unconfined security, secure tranquility, delightful happiness, happy eternity, eternal blessedness, the vision of truth, and praise, O God. Amen.

“Qua Ad Caelum Adspirit (For the Attainment of Heaven)” (2000, pp. 52-57). ${ }^{26}$

The words "grant me knowledge of you, the first truth, and enjoyment of your divine majesty" are closely associated with the goal of the theological virtue of hope, namely personal union with God. There are many other words and phrases, however, that might seem surprisingly "earthy," such as "a river of delights ... a delightful garden beneath my feet ... the glorification of body and soul ... the sweet companionship of men and angels ... a multitude of dwelling places ... the cheerfulness of spring, the brilliance of summer, the fruitfulness of autumn, and the gentle repose of winter." These latter goods most clearly correspond to Aquinas's expectations for the final resurrection of the dead and they seem, at least in part, to be goods desired by the corporal senses as well as the intellect.

\footnotetext{
${ }^{26}$ The original text is: "Te Deum totius consolationis invoco, qui nihil in nobis praeter tua dona cernis, ut mihi post huius vitae terminum donare digneris cognitionem primae veritatis, fruitionem divinae maiestatis. Da etiam corpori meo, largissime remunerator, claritatis pulchritudinem, agilitatis promptitudinem, subtilitatis aptitudinem, impassibilitatis fortitudinem. Apponas istis affluentiam divitiarum, influentiam deliciarum, confluentiam bonorum, ut gaudere possim supra me de tua consolatione, infra de loci amoenitate, intra de corporis et animae glorificatione, iuxta de Angelorum et hominum delectabili associatione. Consequatur apud te, clementissime Pater, mea rationalis potentia sapientiae illustrationem, concupiscibilis desiderabilium adeptionem, irascibilis triumphi laudem: ubi est, apud te, evasio periculorum, distinctio mansionum, concordia voluntatum; ubi est amoenitas vernalis, luciditas aestivalis, ubertas autumnalis, et requies hiemalis. Da, Domine Deus, vitam sine morte, Gaudium sine dolore: ubi est summa libertas, libera securitas, secura tranquillitas, iucunda felicitas, felix aeternitas, aeterna beatitudo, veritatis visio, atque laudatio, Deus. Amen.” This Latin text can be found in Aquinas (1954, vol. II, p. 288).
} 
This latter point is important, first, because the formal goal of hope, union with God, has a context, described in traditional Christian metaphors and art in terms of a glorious Kingdom that will give sensory as well as intellectual and spiritual delight. Consistent with this satisfaction of sensory desires, Aquinas defends not only the theological virtue of hope but also the existence of a corresponding passion (passio) of hope, which Aquinas describes in ST I-II, q.40 as the first of the "irascible" passions, concerned with the yearning for difficult-to-obtain goods.

The relation of the passion and virtue of hope is still a matter of some scholarly debate, but on this point I take the view that is also defended by Christopher Bobier (2020), ${ }^{27}$ namely that Aquinas's account of the passion is shaped by the theological virtue, and that both the passion and virtue have the same object, the Kingdom of Heaven, albeit with diverse aspects desired by diverse appetites of the same person. The point serves as a reminder that ultimate goal of human flourishing, in Aquinas's account, is not simply that of a disembodied soul but that of body and soul together, made pure and holy in glory.

\subsection{Concluding Remarks}

Hope, the supernatural virtue of desire for the happiness of heaven, appears the most "natural" of the triad of theological virtues accepted in the Middle Ages. First, hope is about the first-personal desire for complete and perfect happiness, a desire that is also natural to all human beings, as Aristotle famously argued, even though unaided human reason cannot articulate very clearly what this happiness means. Second, both Aristotle's Nicomachean Ethics and Aquinas's prayer for heaven agree on this point at least, that this desire for happiness is not for any ordinary state of present existence, but for something complete and permanent. ${ }^{28}$ Hence although hope is properly for a goal that can only be known through revelation, the desire of hope aligns closely with our unaided natural desires.

Hope is also natural in the sense that it belongs specifically to the present life with which we are familiar, a life in which one desires happiness, and may have a prospect of attaining it, but one does not yet possess it. At best, on the second-person account, one may have a certain foretaste of happiness from a union with God as co-attending subject in the life of grace, but not yet as the direct object of one's attention, face-toface. On this point, Aquinas adds that the souls in purgatory also have hope and for the same reasons, but there is no hope in hell because happiness cannot be attained

\footnotetext{
${ }^{27}$ Note that this publication is forthcoming at the time of writing, so I cannot give a more precise reference.

${ }^{28}$ See, for example, the Nicomachean Ethics, I.9-10, especially 1100a9-14, in which Aristotle points to the fact that no one is securely happy while alive, and yet happiness is an activity which seems incompatible with being dead. Hence Aristotle seems to suggest that there is or ought to be a state of happy activity that is complete and free from any prospect of its loss.
} 
from this state, and there is no hope in heaven insofar as all such desire is finally and permanently satisfied.

Given these considerations, it might seem that the medieval account of theological hope cannot be other than an historical curiosity to a contemporary world in which there is widespread unbelief in the existence of God or heaven. Nevertheless, there have been some recent and well-received scholarly attempts to argue that hope can breathe new life into contemporary humanism and contribute to the good life of the earthly city, as well as looking to Kingdom of God. ${ }^{29}$

Moreover, it is not difficult to find multiple references to such hope simply by visiting any supermarket or retailer that uses advertising. Such a setting for selling temporal goods might seem a strange place for finding evidence of transcendent desires. Nevertheless, I have found many goods that offer, for example, "snacking nirvana," or "bliss," or "paradise," or "heaven," or products, such as from a famous coffee company, that promised to warm my soul, not just my stomach. The prevalence of this soft-focus religious language, to sell everything from holidays to oatmeal, witnesses to a confidence that human beings have at least an inchoate desire for the happiness of heaven regardless of their personal religious commitment. This desire belongs to what the Middle Ages would classify as the passion of hope rather than the theological virtue, but the desire is clearly strong enough, not only to be acknowledged, but to have become a central theme of massive investment, even in a secular age.

\section{References}

Aquinas, T. (1954). Thomae Aquinatis Doctoris Angelici Opuscula Theologica, 2 vols. Marietti. Aquinas, T. (2000). The Aquinas prayer book: The prayers and hymns of St Thomas Aquinas (R. Anderson \& J. M. Moser, Trans.). Sophia Institute Press.

Aquinas, T. (1911). The 'Summa Theologica' of St. Thomas Aquinas, literally translated by the fathers of the English Dominican Province. Burns, Oates and Washbourne Ltd.

Bejczy, I. P. (2005). The Problem of Natural Virtue. In I. P. Bejczy \& R. G. Newhauser (Eds.), Virtue and ethics in the Twelfth Century (pp. 133-154). Brill.

Bobier, C. A. (2020). Aquinas on the emotion of hope: A psychological or theological treatment? American Catholic Philosophical Quarterly (forthcoming).

Darwall, S. (2013). Honor, history, and relationship: Essays in second-personal ethics II. Oxford University Press.

Doyle, D. (2011). The promise of Christian humanism: Thomas Aquinas on hope. Crossroad Publishing Company.

Elliot, D. (2017). Hope and Christian ethics. Cambridge University Press.

Gregory I. Pope. (2012). Morals on the book of Job (P. A. Böer, Ed., anon., Trans.), Veritatis Splendor Publications.

Hobson, P. (2005). What puts jointness into joint attention? In N. Eilan, C. Hoerl, T. McCormack, \& J. Roessler (Eds.), Joint attention: Communication and other minds: Issues in philosophy and psychology (pp. 185-204). Oxford University Press.

\footnotetext{
${ }^{29}$ See, for example, Doyle (2011) and Elliot (2017).
} 
Leyser, C. (2000). Authority and asceticism from Augustine to Gregory the Great. Clarendon Press. MacIntyre, A. (2007). After virtue: A study in moral theory, 3rd Edition. University of Notre Dame Press.

Pinckaers, S. (1995). The sources of Christian ethics (M. T. Noble, Trans.). Catholic University of America Press.

Pinsent, A. (2012). The second-person perspective in Aquinas's ethics: Virtues and gifts. Routledge.

Pinsent, A. (2017). Who's afraid of the infused virtues? Dispositional infusion, human and divine. In H. Goris \& H. Schoot (Eds.), The virtuous life: Thomas Aquinas on the theological nature of moral virtues (pp. 73-96). Peeters.

Southern, R. W. (1997). Scholastic humanism and the unification of Europe: Foundations. John Wiley \& Sons.

Stump, E. (2018). Atonement. Oxford University Press.

Stump, E. (2011). The non-Aristotelian character of Aquinas's ethics: Aquinas on the passions. Faith and Philosophy 28(1), 29-43.

Thorold, A., \& K. Marcellino, trans. (2011). The dialogue of Saint Catherine of Siena: Modern English edition. Lighthouse Publishing.

Andrew Pinsent (Ph.D.) is Research Director of the Ian Ramsey Centre for Science and Religion at the Faculty of Theology and Religion, University of Oxford. Formerly a particle physicist on the DELPHI experiment at CERN, he is now a Catholic priest trained at the Pontifical Gregorian University. He has degrees in philosophy and theology and a second doctorate, in philosophy. A major theme of his research is second-person relatedness in science, philosophy, and theology. His publications include work in virtue ethics, neurotheology, science and religion, the philosophy of the person, insight, divine action, and the nature of evil. At Oxford, he has been Principal Investigator for more than $\$ 8$ million of research grants involving scholars in more than a dozen countries. In the media, in schools, and at a great diversity of other venues, he is a regular contributor to public engagement with science and faith issues.

Open Access This chapter is licensed under the terms of the Creative Commons Attribution 4.0 International License (http://creativecommons.org/licenses/by/4.0/), which permits use, sharing, adaptation, distribution and reproduction in any medium or format, as long as you give appropriate credit to the original author(s) and the source, provide a link to the Creative Commons licence and indicate if changes were made.

The images or other third party material in this chapter are included in the chapter's Creative Commons licence, unless indicated otherwise in a credit line to the material. If material is not included in the chapter's Creative Commons licence and your intended use is not permitted by statutory regulation or exceeds the permitted use, you will need to obtain permission directly from the copyright holder.

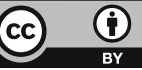

